\title{
MODERN ECONOMIC AND LOGISTICAL TRENDS IN EURASIA: HOW DO NEW TRANS- EURASIAN MEGA-PROJECTS INFLUENT TO NATIONAL ECONOMIC GROWTH
}

\author{
Aliaksei Audonin ${ }^{1}$, Ardak Turginbayeva ${ }^{2 *}$, Askar Askerov², Dimash Yergobek ${ }^{2}$ \\ ${ }^{1}$ Expert of the Belarusian public organization "Belaya Rus", Minsk, Republic of Belarus \\ ${ }^{2}$ Al-Farabi Kazakh National University, 050040, 71, al-Farabi Ave, Almaty, Kazakhstan
}

\begin{abstract}
The development of trade and communication technologies impact on economic processes and accelerate the interaction processes. The article considers modern transport and logistics projects on the Eurasian continent, both rail and sea, reveals the development trends of air transport. The main attention is paid to the impact of such projects on the economic growth of the countries of the region and international processes. The article reflects the key stages of the implementation of the Chinese project "One Belt One Road" in Kazakhstan, the Russian Federation and the Republic of Belarus. The final conclusion of the article is an idea that the intensive development of transport communications is important for raising national economies, transport arteries should be constructed not only within the country, but also on the Eurasian continent. The article has a practical importance for government departments, organizations and experts related to the study of geo-economic processes and up making decisions in the field of public administration.
\end{abstract}

\section{Introduction}

In current development of communication and logistics technologies, modern geo-economic processes and projects on the Eurasian continent have an objective integration effect on all countries. The influence of huge transport and trade projects in Eurasia is the most relevant in the context of growing trade contradictions and changes in the former institutions of world trade.

The proposed study differs from the similar ones in its desire to comprehensively describe the impact of various projects and technologies for the delivery of goods from East to West and vice versa ("One Belt One Way", "Northern Sea Route", high-speed transport) on the national economies of the country (Kazakhstan, Belarus, Russian Federation) involved in these processes. Object of study: geo-economic processes in Eurasia. Subject of research: the

\footnotetext{
* Corresponding author: turginan@gmail.com
} 
impact of global transport and logistics projects on national economies and integration processes. Purpose: to determine the relationship of large geo-economic projects on national economies. Objective: consideration of the implementation of the PRC, RF transport and logistics projects on the Eurasian continent

Method: general scientific methods in the framework of comparative, logistic and statistical analysis.

\section{Literature review}

There are several authors who are researched this theme. Henk Zijm, Matthias Klumpp, they wrote about the result of global societal and economic as well as technological developments logistics and supply chains face unprecedented challenges [1].

Magee, J. F., et al wrote about management logistics which is maximize the economic value of products or materials [2].

E. Muller researched logistics is of great significance to China. The changes of outside environment in the world must be considered in logistics [3].

Yu-ling, Y. U. wrote about the continuous perfection of socialist market economy system, China's logistic infrastructure has been constructed,logistics scale has been expanded,and the concepts, forms and approaches to management have also been changed [4].

Da, C. wrote about modern green logistics management, as a kind of new logistics management mode, accords with the developmental requirement of the times and the benefit of human survival and development, and represents the developmental direction and trend of future logistics management [5].

Wang, J. J., et al wrote about description of the development of the logistics, analyzing the definition of the E-logistics, comparing the E-logistics with the traditional logistics from four aspects [6].

Kovács, G., \& Kot, S. researched the growing market globalization, increasing global competition, and more complex products results application of new technologies, methods and business processes [7].

\section{Discussion}

Transport is an integral part of foreign trade relationships between countries.

Transport communication in the form of roads, railways, air infrastructure, pipelines are, as you know, the "arteries" of the economy.

Their level (speed capabilities), length, quality directly affects the development of trade cooperation inside the country and between states.

In human history, you can find a significant number of examples when to unite the country, increase trade, economic development, and therefore political authorities paid special attention to the construction of such "arteries" (stone roads - Greek civilization, Roman Empire, Railways - European countries, Russian Empire, USA, Highways Germany, USSR, USA; Aviation - USA, USSR, EU, China, etc.).

Trade turnover and economic growth are directly depended on transport and routes (poor infrastructure and old transport, aircraft, rolling stock, etc. decrease trade).

In current conditions, the particular importance gets the time of delivery of goods and passengers from one extreme point of Eurasia (from China) to another extreme point (to EU, for Ex).

Let us look at the main logistic trends on the Eurasian continent.

They are: 
1. The China project One Belt One Road (both - Railway and Sea)

2. Northern Sea Route

3. High-speed transport (future trends)

The Chinese saying: "To get rich, you must build a road first". China is working to revive the ancient Silk Road trade routes from Asia to Europe under its transnational megaproject called the Belt and Road initiative [8].

China's multi-trillion-dollar belt and road plan aims to boost trade and infrastructure links across Asia, Africa and Europe.

It takes its name from the ancient Silk Road that connected the ancient empires of China and Rome.

The first announcement of Economic Belt of the Silk Road (EBSR) has been made by Chinese President Xi Jinping on September 7th, 2013 exactly in Astana [9].

The "One Belt" is a huge transport project stretches to the Baltic Sea area via Central Asia and Russia, to the Mediterranean Sea area via Central Asia and Western Asia, and to the Indian Ocean area via southwest China. EBSR has become an open platform for economic cooperation between the Eurasian Economic Union and the Asia-Pacific region.

With a huge US\$900bn worth of planned investments to build railways, ports and other infrastructure in 65 countries along the routes, the Belt and Road initiative is historically the biggest foreign investment strategy by any single country in world history. China has already invested more then 5-7bn US\$ to different countries during this past decade [10].

Here you can see the main country-points of this projects. Kazakhstan, Kyrgyzstan, Tajikistan, Uzbekistan, and Turkmenistan are just across the border from China. They are closely connected with China's economy [11].

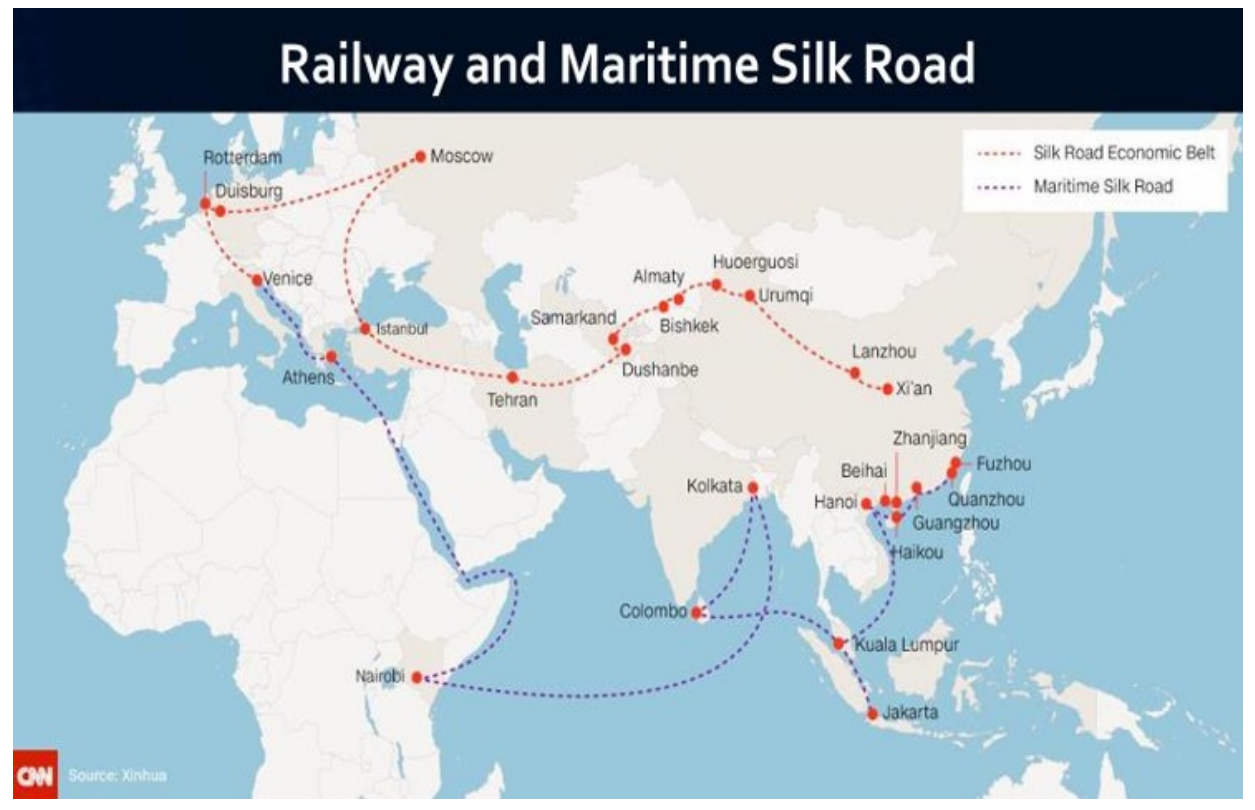

Fig. 1 Railway and Marytime Silk Road. Source: CNN.

Announced by President of Kazakhstan Nursultan Nazarbayev in November 2014, the Nurly Zhol (Bright Road) new economic policy largely corresponds with the plans for the development of EBSR [12]. 
Until 2020, it is planned to implement projects with a total investment of about $\$ 40$ billion. Until the end of 2015, it is planned to attract $\$ 5$ billion from four leading international banks for the construction of roads in the Centre - South, Centre - East and Center - West directions. This is how the task set in Nurly Zhol of connecting the capital with major regions on the radiation principle will be implemented.

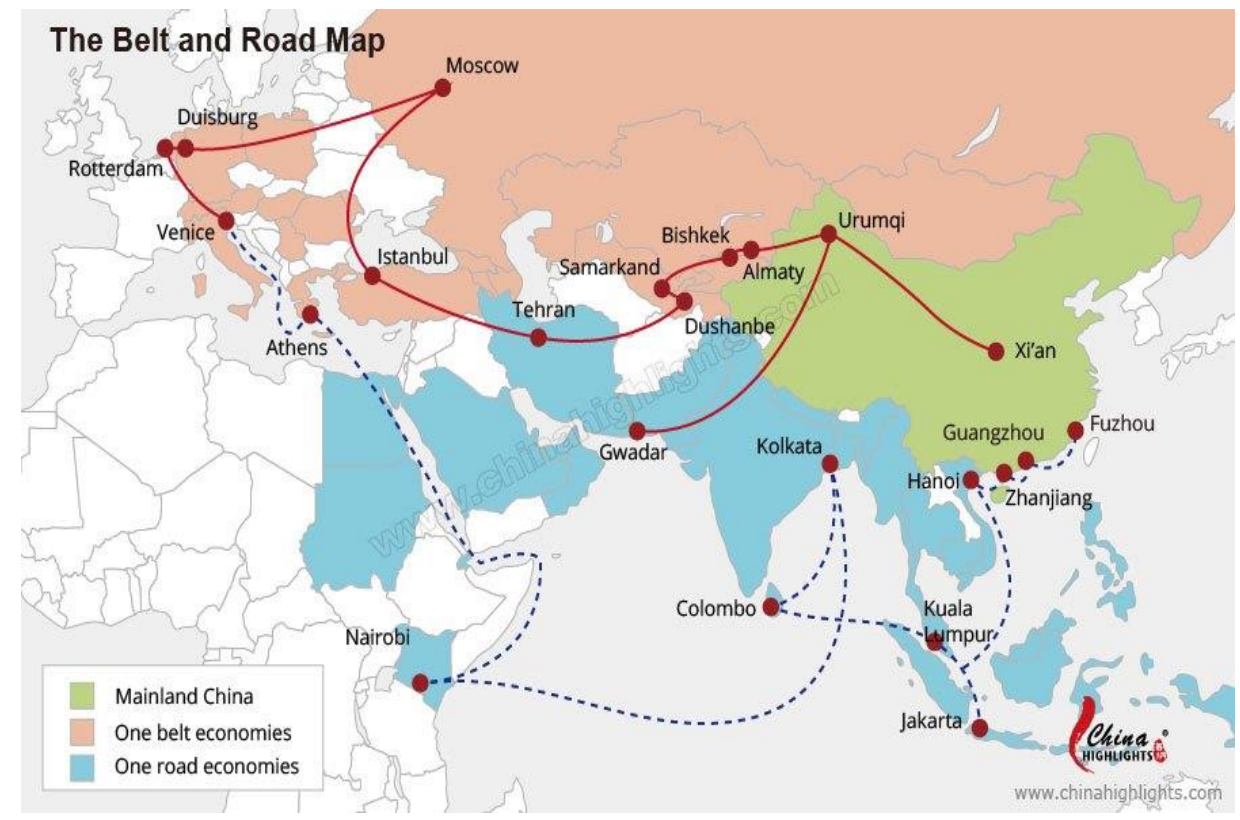

Fig. 2. Railway and Marytime Silk Road. Source: www.chinahighlight.com.

Launched into operation in recent years, sections of the international highway Western China - Western Europe, as well as the Kazakhstan-Turkmenistan-Iran-Persian Gulf railway, can be an organic part of the modern Silk Road routes.

The Silk Road is back. KZ is taking advantage. Since 2014, some $\$ 20$ billion in Chinese investment has poured into KZ, with around $\$ 8$ billion in 2017 [13].

Earlier, in 2008, Kazakhstan began construction of the West Europe-West China Highway, which will stretch from the Lianyungang port on the Yellow Sea to St. Petersburg on the Baltic Sea. By 2016, China and Kazakhstan had completed their parts of the project, and Kazakhstani president Nursultan Nazarbayev had to call on Russia to finish its section. The highway is also connected to the Khorgos-Eastern Gate SEZ. In 2014 the parties also signed an agreement on building a joint logistics terminal at Lianyungang, giving landlocked Kazakhstan its "window to the sea." [14]

The Asian Infrastructure Investment Bank is the driver of these and other projects with capital of $\$ 100$ billion along with the Silk Road Fund with $\$ 40$ billion.

In 2014 China and Kazakhstan have launched the joint venture Kazakhstan-China International Logistics Company of port Lianyungang, which grants Kazakhstan access to China's eastern seaboard (Weitz, 2014). The Kazakhstan Temir Zholy (KTZ), the stateowned national railway company, plans to invest $\$ 100$ million in the construction of a logistics hub at the port in Lianyungang [15].

In 2017 Kazakhstan sold a 49\% stake of its Khorgos Dry Port to two Chinese companies, China COSCO Shipping Corporation and Jiangsu Lianyungang Port Co,which each owning $24,5 \%$. 
On the China side, Khorgos is positioned as the western Shenzhen, a huge transportation hub, which is expected to develop quickly because of trade with Europe.

Kazakhstan's new Caspian Sea ferry port, known as Kuryk, was funded in part by Chinese capital. It launched this year with a million tons of cargo expected in 2017 . The goal was simple: Kuryk makes it possible to triple KZ's existing ferry capacities, available through a nearby port of Aktau, and strengthens the Kazakh section of the China-Europe transport corridor.

China gets secure access to Kazakhstan resources and promises that if Kazakhstan develops a port, which helps ship Chinese goods, they will get the financing to Kazakhstan banks. Kazakhstan banks get access to Chinese capital and Kazakhstan companies can sell raw materials into China [16].

Why is it so preferable for other countries? Because it has a huge amount of price and time advantage for costumers and contains a lot of profit.

The shortest travel time for rail freight between China and Europe is ten days, providing an alternative shipping method that is cheaper than air freight and faster than shipping by sea.

"After the launch of China Railway Express to Europe, we have provided a third option for clients who need fast transport and are sensitive about price. The market is huge. Fang Xudong, who is in charge of the Yiwu-Madrid line on the China Railway Express to Europe, told CCTV.

The One Belt One Road Project contains the construction of different industrial parks like Great Stone Park in Belarus through the whole way from China to Europe.

Since 2011, China has sent a total of 11,000 freight trains to Europe and back as part of its Belt and Road initiative.

Driven by subsidies offered under the initiative, a total of 65 freight rail routes have now been opened between Chinese cities and 44 cities in 15 European countries, compared to practically none ten years ago.

Rail transport only takes 10-14 days to reach Europe compared to up to 40 days by sea.

All contractors participating in Chinese-funded projects in 34 countries, 89 percent were Chinese companies, 7.6 percent local companies and 3.4 percent foreign companies.

Chinese foreign direct investment in 55 Belt and Road countries stood at US\$10.78bn, up 12.3 percent year-on-year, according to China's Ministry of Commerce [17].

More than 1,000 cargo trains heading to and from Europe were handled by a single railway port in Chengdu, the capital of southwestern China's Sichuan Province, in 2017

Chengdu International Railway Port, part of the China (Sichuan) Pilot Free Trade Zone, is the backbone of the region's plan to establish a global logistics system. This year it ranked first in the country for daily opening and operation, handling 2-3 trains every day.

Located at the junction of China's Silk Road and Yangtze River economic belts, the 9.68square-kilometre port forms a Y-shaped international logistics channel.

Despite the rapid growth in routes and volume, trains carried only

2.1 percent of total China-Europe trade by value in 2017 , compared to

64 percent by sea,

28 percent by air and

6 percent by road,

according to a study published earlier this year by the Washington-based Center for Strategic and International Studies (CSIS).

Chinese companies are carrying out more than 20 railway projects overseas, amounting to a total investment of $100 \mathrm{bn}$ yuan (US\$15bn).

The China Railway Rolling Stock Corporation (CRRC) has 75 branches and 13 R\&D centers in 26 countries and regions. Its overseas contracts in 2017 were worth US\$8-10bn.

In 2017 China's COSCO shipping and Lianyungang Port took a 49\% cut of Kazakhstan's epic Khorgos Gateway dry port on the Kazakh/China border 
In this article we should also mentioned about Japan- Kazakhstan transport projects. In 2017, Japan's Nippon Express logistics firm has signed an MoU with Kazakh Railways (KTZ) to increase the overland flow of container traffic between the Japan/South Korea region and Central Asia, the Caucasus, and Europe. Nippon Express provides the cargo and KTZ handles the transshipment and processing of the containers through Kazakhstan.

Russian Federation.

Since the bulk of freight traffic in the delivery of goods from the East to Europe falls on the territory of Russia, let's look at its traffic structure.

Russia is an important part of the Silk Road Economic Belt. It has a close relationship with Central Asian countries, the countries of the Caucasus region, and Western Asian countries.

Traditionally, the main share of freight turnover in the Russian Federation is accounted for railway (49.3\%) and pipeline transport (52.38\%) (due to significant territories and export structure (oil, gas)) [18].

Currently, the average speed of passenger rolling stock in countries with high GDP and high economic growth is more than $150-170 \mathrm{~km} / \mathrm{h}$ (that's average, not to be confused with the so-called "running" speed and speed train records $-370 \mathrm{~km} / \mathrm{h}, 603 \mathrm{~km} / \mathrm{h}$ (Japanese train MLX01 magnetic levitation, and 574,8 $\mathrm{km} / \mathrm{h}$ - a record rail French TGV trains), while in Russia - only about $65-75 \mathrm{~km} / \mathrm{h}$ (excluding high-speed trains Moscow - Nizhny Novogorod $(113 \mathrm{~km} / \mathrm{h})$ Moscow-St. Petersburg $(153 \mathrm{~km} / \mathrm{h})) /$

Due to the crisis of 2014, the export of TRANS-services in Russia decreased from $\$ 20.75$ billion (2013) to 17.03 (2016), imports - from $\$ 17.5$ to 11.5 billion.

Exports of trips to Russia decreased from $\$ 11.98$ billion to $\$ 7.78$ billion. imports - from 53.45 to 23.95 billion. USA;

The greatest decrease was defined in road transport, due to a down falling in demand of this type of service in the Russian Federation and decrease of the population income. Less income - less consumption of goods - less volume of cargo turnover.

Republic of Belarus.

Belarus is an integral part of The One Belt One Road Project linking Russian transport infrastructure to Europe (to Poland and to Baltic states). About Belarusian transport statistic you can read more on the site of National Statistical Committee of the Republic of Belarus [19]. The One Belt One Road Project gave opportunity to open new direct railway route from Orsha (Belarusian transport hub) to China and increased the export of food products and other national goods to china market [20].

Transit routes connecting the countries of Western Europe with Russia pass through the territory of the Republic. From north to south it is crossed by transport routes between the countries of Scandinavia, the Baltic states and Ukraine, and Moldova.

In Belarus there are two of the 10 trans-European transport corridors, pass through the territory of the Republic: Berlin - Minsk - Moscow; Helsinki - Mogilev - Bucharest.

For Belarus it is important two parts of transcontinental railway: the $1^{\text {st }}$ crossing Eurasia from the Atlantic to the Pacific Ocean (within Belarus, Brest - Orsha) and the 2nd Transcontinental railway in the framework of the Chinese project «One belt - One way» (New Silk Road).

The central position of Belarus in Europe is important for the development of international tourism, the organization of interstate financial institutions, etc. The distance from Minsk to the capitals of our neighbors is small: to Vilnius - $215 \mathrm{~km}$; to Riga - $470 \mathrm{~km}$; to Warsaw - $550 \mathrm{~km}$; to Kiev - $580 \mathrm{~km}$; Moscow is $700 \mathrm{~km}$ away.

More over the New Silk Road Project contains the construction of different industrial parks like Great Stone Industrial Park in Belarus through the whole way from China to Europe [21]. 


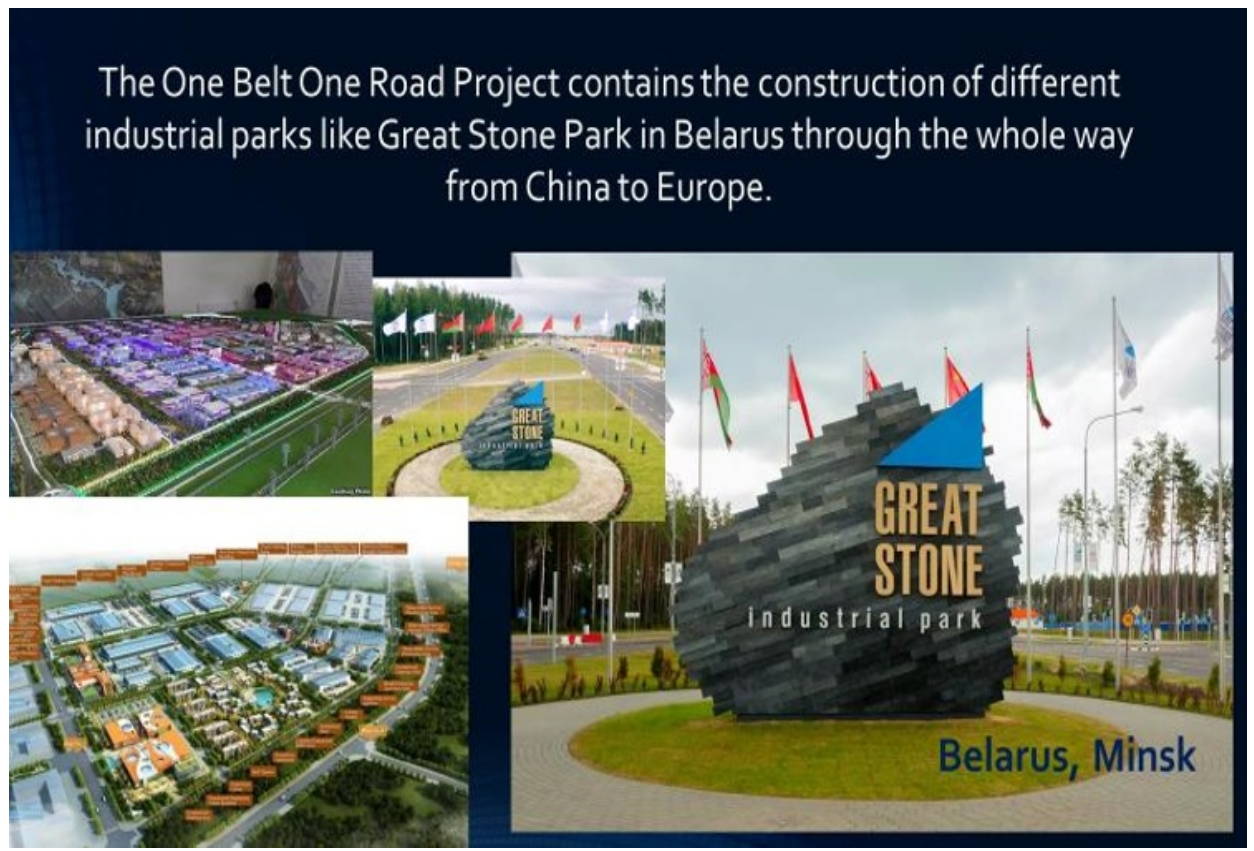

Fig. 3 Great Stone Project in Belarus. Note - compiled by the author based on the source https://industrialpark.by/.

The future of the Air Transport.

According to forecasts of Boeing [22], in the next 20 years on the territory of the CIS countries will be a constant growth of international traffic at the level of 5.3\% per year, which will lead to a sharp increase in demand for single-aisle aircraft (such as Airbus A320, Boeing 737, Tu-204, McDonnell Douglas DC-9, McDonnell Douglas MD-80 and others), as well as on wide-body aircraft (single-deck A300, A310, A330, A340, A350, Boeing 767, 777 and 787 and the Il-86 and Il-96, double-deck Boeing 747 and A380).

It is expected that airlines will need 830 narrow-body and 160 wide-body aircraft to cover the increasing passenger traffic by 2036.

Additionally, it is expected that $1 / 3$ of the new aircraft deliveries will replace the outdated fleet.

The total share of narrow-body aircraft worldwide from 2016 to 2036 will increase from $62 \%$ to $71 \%$ of the total number of aircraft, wide - body-from $10 \%$ to $12 \%$, and the share of regional aircraft will decrease from $28 \%$ to $18 \%$.

At the same time, the volume of LCC (Low-Cost Carrier, or low-cost carriers) is expected to grow. According to Boeing, in 2017, the share of LLC in Europe accounts for 37\% of the total seats (or 23 million $\mathrm{p} / \mathrm{m}$ ), North America - 31\% (from 21 million $\mathrm{p} / \mathrm{m}$ ), China - 4\% (from 14 million $\mathrm{p} / \mathrm{m}$ ), the highest level of LLC in South-East Asia - 53\% (with a total of 8 million $\mathrm{p} / \mathrm{m})$.

The Northern sea route.

For understanding the current logistic trends, it is important to look at the projects concerning the development of the Northern sea route - through the Arctic ocean.

This path became possible due to climate change and the creation of modern nuclear icebreakers.

In June 2017, the Arctic region was included in the Belt and Road initiative as the «third blue economic corridor» which is expected to lead to Europe through the Arctic ocean [23]. 


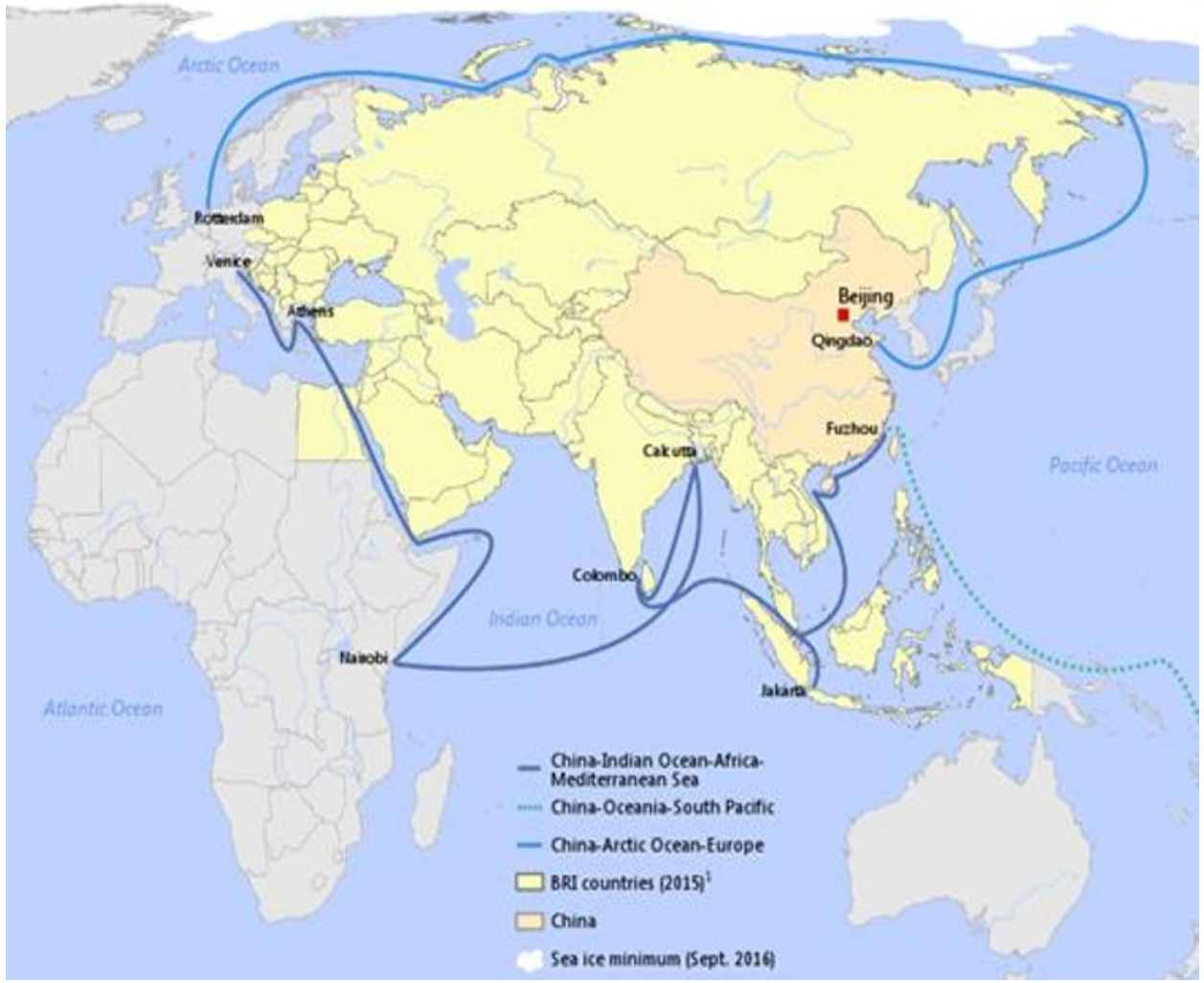

Fig. 4. Map of the Belt and Road Initiative's three maritime routes. Note - compiled by the author based on the source Cryopolitics

From Yokohama to Rotterdam it is 1.7 times shorter and $40 \%$ faster in time (20 days instead of 33).

The Northern route, despite the Arctic specifics, passes mainly in the territorial waters of one state, thereby ensuring not only complete safety from pirates and other similar misfortunes, but also less bureaucracy. And the prices for the calculations are very attractive. To deliver a standard TEU from Shanghai to St. Petersburg will cost \$ 2,097., that is 9-11\% cheaper than the «southern» option.

High-speed transport.

To understand the future Eurasian Logistic trend, it is important to take into account the new high-speed transport development. This technology can dramatically change the economic and logistic relationships between Eurasian states.

In August 2017 the China Aerospace Science and Industry Corporation (CASIC) revealed plans to build a high-speed train which could 'fly' at 4,000 kilometers per hour [24].

Hyperloop technology uses magnets to levitate carriages, known as pods, inside a sealed tube, allowing them to travel up to speeds of $1,200 \mathrm{kph}$ because there is no air resistance or friction. 


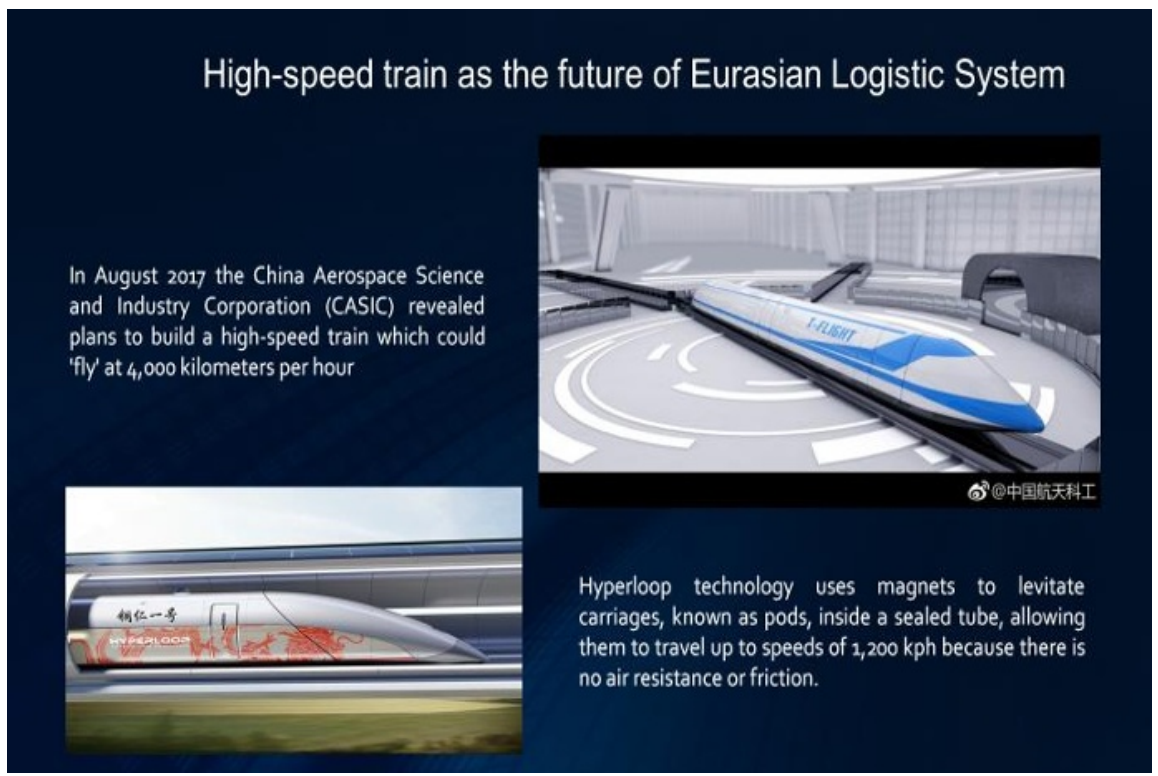

Fig. 5 High-speed transport. Note - compiled by the author based on the source CASIC.

\section{Conclusion}

This article shows the influence of modern logistic project to national economics. The main idea - to accelerate economic growth by increasing the level of turnover of goods and passengers (consumers - «carriers» of funds) it needs high speed on the railway and roads and their relatively low cost.

To accelerate the integration processes and economic growth it is rather important to decrease the time of delivery of goods and passengers and the cost level.

\section{References}

1. H. Zijm, M. Klumpp, Future Logistics: What to expect, how to adapt. In Dynamics in logistics (pp. 365-379). Springer, Cham. (2017).

2. J. F. Magee, W. F. Capacino, W. C. Copacino, D. B. Rosenfield, Modern logistics management: Integrating marketing, manufacturing and physical distribution (Vol. 22). John Wiley \& Sons. (1985).

3. E. Muller, Modern Logistics System [J]. Logistics and Material Handling, (1) 354-356 (1996).

4. Y. U. A. N. Yu-ling, Present situation of logistics in China and its developing trends [J]. Journal of Chang'an University (Social Science Edition), P. 2. (2006).

5. Da, C. Research of modern green logistics management and its strategy [J]. China Population, Resources and Environment, 2. (2001).

6. J. J. Wang, D. L.Yang, E-logistics: New trend of the modern logistics [J]. Journal of Dalian University of Technology (Social Sciences), 2. (2005).

7. G. Kovács, S. Kot. New logistics and production trends as the effect of global economy changes. Polish Journal of Management Studies, 14. (2016).

8. GBTime, Jul 01, https://gbtimes.com/chinas-deal-with-italian-firms-will-rescue-lake$\underline{\operatorname{chad}(2018)}$ 
9. Scientific articles Kazakhstan https://articlekz.com/en/article/21512

10. GBTime, May 09, 2017 https://gbtimes.com/chinas-belt-and-road-initiative-explained

11. The New Silk Road - The Belt and Road Initiative https://www.chinahighlights.com/silkroad/new-silk-road.htm

12. Kazakhstan's Nurly Zhol and China's Economic Belt of the Silk Road: Confluence of Goals, The Astana Times, Sep. 222015 https://astanatimes.com/2015/09/kazakhstansnurly-zhol-and-chinas-economic-belt-of-the-silk-road-confluence-of-goals/

13. Kazakhstan Bets Big On China's Silk Road, Forbes, Jul. 182017 https://www.forbes.com/sites/kenrapoza/2017/07/18/kazakhstan-bets-big-on-chinassilk-road/\#7273c6cd5805

14. Kassenova, Nargis. China's Silk Road and Kazakhstan's Bright Path: Linking Dreams of Prosperity https://www.questia.com/library/journal/1P4-2125229219/china-s-silk-roadand-kazakhstan-s-bright-path-linking

15. Ryskeldi Satke, Franco Galdini. Between East and West: Kazakhstan's development along China's new Silk Road, http://www.osceacademy.net/upload/file/Between_East_and_West.pdf

16. Chinese companies buy stake in dry port in Kazakhstan, 2017 (05-15) http://www.chinadaily.com.cn/business/2017-05/15/content_29355527.htm

17. Wade Shepard. Khorgos: The Central Station Of The New Silk Road Has Emerged, https://www.forbes.com/sites/wadeshepard/2017/04/29/the-central-station-of-the-newsilk-road-has-emerged/\#3be70c8f1 fdd

18. Freightweek https://www.freightweek.org/index.php/en/corporate-news-2/2792-nipponexpress-signs-kazakhstan-mou

19. Transport, National Statistical Committee of the Republic of Belarus http://www.belstat.gov.by/ofitsialnaya-statistika/realny-sector-ekonomiki/transport/

20. BaPayUnionState http://www.nbrb.by/publications/BalPayUnionState

21. Great Stone Industrial Park https://industrialpark.by/

22. CURRENT MARKET OUTLOOK 2017-2036, Boeing, 2017 http://www.boeing.com/resources/boeingdotcom/commercial/market/current-marketoutlook-2017/assets/downloads/2017-cmo-6-19.pdf

23. Mia Bennett, Cryopolitics, June 27, 2017, With the Polar Silk Road, China's Belt and Road Initiative moves into the Arctic, https://www.cryopolitics.com/2017/06/27/chinasbelt-and-road-initiative-moves-into-the-arctic/

24. GBTIMES Beijing, Aug 30, 2017 https://gbtimes.com/china-plans-hyperloop-train-maxspeed-4000-kmh 